Sławomir Sobieraj

ORCID: 0000-0001-6332-692X

Uniwersytet Przyrodniczo-Humanistyczny w Siedlcach

\title{
KOHERENCJA MITÓW ODRODZENIA NATURY, CZŁOWIEKA I OJCZYZNY W PÓŹNYCH WIERSZACH TADEUSZA MICIŃSKIEGO (HYMN, WIDZENIE POLSKI)
}

https://doi.org/10.34739/clit.2020.14.16

THE COHERENCE OF MYTHS OF THE REVIVAL OF NATURE, HUMAN AND HOMELAND IN THE LATE POEMS OF TADEUSZ MICIŃSKI (HYMN/ANTHEM, WIDZENIE POLSKI/VISION OF POLAND)

The article presents interpretations of the little-known late poetry of Tadeusz Miciński from 1914-1915, where the myth of revival occurs. It has been shown that alongside with the myths of individual and national revival found in the writer's earlier works, there appears the rite of renewal of nature, which functions in the close connection with them in the poems Hymn/Anthem and Widzenie Polski/Vision of Poland. This is the new formula of the author's lyrics. It has been proved that the coherence of the mentioned myths is subordinated to the idea of renouncing personal happiness in favor of the national cause and the vision of resurrection of the homeland (Poland) in specific geographical dimension. Attention was paid to the symbolism of the language of the analyzed texts.

Keywords: Tadeusz Miciński, poetry, myth of revival, nature, homeland, symbolism

\section{Liryka znana i mniej znana}

Tadeusz Miciński jako poeta jest znany i ceniony przede wszystkim ze względu na autorstwo pierwszego i jedynego zbioru liryki wydanego za życia - W mroku gwiazd (1902). Dzieło to stanowi o jego wysokiej pozycji na parnasie literatury polskiej przełomu dziewiętnastego i dwudziestego wieku. Nie można jednak zapominać, że istnieją jeszcze inne utwory 
poetyckie młodopolskiego „maga”, powstałe z reguły w późniejszym okresie, które cząstkowo włączano do powojennych wyborów wierszy². Szczególną uwagę literaturoznawców przykuwały intrygujące teksty z cyklu Kaukaz, drukowane pierwotnie w „Ateneum” w 1903 r., a pomieszczone również w powieści Nietota. Jednak przez długie lata zupełnie po macoszemu traktowano poematy $\mathrm{z}$ czasu wojny, rozproszone $\mathrm{w}$ trudno dostępnych polskojęzycznych pismach, które ukazywały się w Rosji. O ich istnieniu badacze jedynie sygnalizowali, wyjątkowo tylko kilka $\mathrm{z}$ nich przedrukowano3. W ogóle mniejsze znaczenie przypisywano późnym wierszom Micińskiego, pochodzącym z drugiej dekady dwudziestego wieku, w których do głosu dochodziły treści ideologiczne i narodowe, spychając na plan dalszy zagadnienia natury egzystencjalnej. Zazwyczaj były one komentowane dość krytycznie, historycy literatury dopatrywali się w nich obniżenia poziomu artystycznego twórczości, rezygnacji z pisarstwa sensu stricto na rzecz działalności publicystycznej4. W ostatnich latach znowu podjęto wzmożone prace nad zapoznaną spuścizną poetycką autora Do źródet duszy polskiej, które doprowadziły do odkrycia nieznanych dotąd wierszy. Anna Wydrycka dotarła do tekstów: Ojczyzna!... i Dzwon Wawelu... w Piotrogrodzie!...5, podając je do druku' ${ }^{6}$, o odnalezieniu Hymnu

\footnotetext{
${ }^{1}$ Jako pierwszy użył chyba tego określenia wobec Micińskiego (swojego starszego przyjaciela) Witkacy w autobiograficznej, niedrukowanej za jego życia powieści z kluczem, która była pisana w latach 1910-1911. Nazwał w niej swojego starszego przyjaciela Magiem Childerykiem. Zob. St.I. Witkiewicz, 622 upadki Bunga, czyli Demoniczna kobieta, wstęp i oprac. A. Micińska, Warszawa 1972.

2 Zob. T. Miciński, Poezje, oprac. J. Prokop, Kraków - Wrocław 1980, wyd. 2. 1984; T. Miciński, Poematy proza, oprac. W. Gutowski, Kraków - Wrocław 1985; T. Miciński, Wybór poezji, wstęp i oprac. W. Gutowski, Kraków 1999.

3 Zob. A. Wydrycka, Zapomniane teksty Micińskiego, „Ruch Literacki” 1989, z. 4-5, s. 381-394. 4 Zob. W. Gutowski, Wstęp, [w:] T. Miciński, Wybór poezji, op. cit., s. 63-64. Badacz wypowiada dość ambiwalentne sądy na temat odejścia poety po 1905 r. od symboliki egzystencjalnometafizycznej na rzecz „historiozoficznych ilustracji”, instrumentalnego traktowania tradycji narodowej i religii oraz agitacyjności tych utworów. Jednocześnie pisząc o „słabości” przywoływanych wierszy, wskazuje na inne, jak np. poemat Jan Lejdy, który miałby być przykładem nowatorstwa i oryginalności, dorównującym wcześniejszym dokonaniom Micińskiego. Zastrzega, że trudno jest jednak w tym wypadku mówić o regresie twórczości (ibidem).

5 Poemat ten był cytowany (bez podawania tytułu) we wspomnieniach Zygmunta Wasilewskiego na początku dwudziestolecia (Z. Wasilewski, Miciński i jego los, „Gazeta Warszawska" 1925, $\mathrm{nr}$ 75, s. 8), o czym pisałem w artykule poświęconym wojennej publicystyce autora Xiędza Fausta, zob. S. Sobieraj, Publicystyka Tadeusza Micińskiego $w$ dobie Wielkiej Wojny, [w:] Czytać Tadeusza Micińskiego. Studia, red. A. Czyż, M. Pliszka, S. Sobieraj, Siedlce 2016, s. 180.

${ }^{6}$ A. Wydrycka, Tadeusz Miciński i Pierwszy Zjazd Wojskowych Polskich w Piotrogrodzie w 1917 roku. Zapomniane artykuty i poematy, [w:] Proza Tadeusza Micińskiego. Studia, red. M. Bajko, W. Gutowski, J. Ławski, Białystok 2017, s. 169-174, 183-186, 194-204.
} 
do Ameryki Zjednoczonych Stanów wspominał w swojej relacji z badań nad wojenną twórczością pisarza Jarosław Ławski. Te literackie znaleziska - jak słusznie zauważał - zmieniają obraz „późnego” Micińskiego. Jego zdaniem, dotyczy to głównie kwestii postaw światopoglądowych i kulturowych predylekcji, wyrażanych $\mathrm{w}$ artykułach o charakterze publicystycznym7, jednak wydaje się, że można je odnieść również do poezji. Zresztą, przywoływany badacz już wcześniej zauważał przemiany poetyki wierszy z wojennej doby, w których najsilniejszym głosem zabrzmiały sprawy narodowe i patriotyzm jako wartość najwyższa. Obecnie, na marginesie artykułu-manifestu Micińskiego z czasów rewolucji, komentuje jego postawę i określa jako wskrzeszanie Mickiewiczowskiej figury poety czynu, zaznaczając przy tym, że ma ona wpływ na „niepiękność” tej liryki ze względu na publicystyczny charakter i dominację perswazyjności ${ }^{8}$.

W moim szkicu chciałbym zwrócić uwagę na dwa nieznane wiersze Micińskiego, powstałe w końcowym okresie jego twórczości, jednak w dużej mierze różne zarówno od innych utworów wychodzących spod jego pióra w tym czasie, jak i od tego, co pisał wcześniej. Myślę tu o tekstach, które zadziwiają pozytywną aurą, wygenerowaną dzięki odwołaniu do świata natury, które nie są przeładowane grandilokwentną frazeologią i leksyką, które wreszcie nie są sprawozdaniami bądź politycznymi deklaracjami, czyniącymi z nich liryczną publicystykę.

Przyjęła się opinia, że liryka Micińskiego otwiera przestrzenie wyobraźni, naznaczone cierpieniem, bólem, ciemnością i melancholią, także często tragicznym rozdarciem jej bohaterów i poczuciem grozy istnienia. Jest to z gruntu rzeczy sąd słuszny w odniesieniu do ponad dziewięćdziesięciu procent tej części dorobku pisarza. Jak zauważa Paweł Próchniak, tonacji pesymistycznej towarzyszy zazwyczaj „dotkliwość” (i można powiedzieć: opresyjność) kreowanej rzeczywistości, cechuje ją jego zdaniem - „silne nasycenie tekstów motywami mieszczącymi się w obszarze, którego centrum wyznacza ból, zorganizowanym wokół obrazu rany"9.

\footnotetext{
7 J. Ławski, Kosmografia wolności. „Nowe” pisma Tadeusza Micińskiego z lat 1914-1917, „Wiek XX. Rocznik Towarzystwa Literackiego im. Adama Mickiewicza” 2018, R. 11, s. 159.

${ }^{8}$ Ibidem, s. 161, 165-166.

9 P. Próchniak, Postscriptum: notatki o czytaniu Micińskiego, [w:] Poezja Tadeusza Micińskiego. Interpretacje, red. A. Czabanowska-Wróbel, P. Próchniak, M. Stala, Kraków 2004, s. 503 .
} 
Biorąc pod uwagę powyższe zdanie, warto pamiętać, że wyobraźnia autora Wity ma charakter oksymoroniczny ${ }^{10}$. W przestrzeniach „czarnych księstw” pojawiają się niekiedy na zasadzie dysonansu oazy szczęścia, a zbuntowani „strąceni z niebiosów” protagoniści tragicznych zmagań ze światem i Bogiem przeżywają chwilę mistycznych uniesień lub pojednań ze sobą w wizjach indywidualnego odrodzenia i manifestacji swojej psychicznej siły (np. w Ananke). Co prawda, przykładów wierszy ukazujących harmonię i duchowy optymizm nie znajdziemy zbyt wiele ani w debiutanckim tomie, ani w utworach późniejszych, jednak kilka z nich dowodzi, że Miciński zarysowywał w swoim projekcie estetyczno-duchowym również widnokrąg spełnienia egzystencjalnego, fundowany na wpisaniu człowieka w krąg boskiego porządku i zbawienia świata. Takie obrazy - „pejzaże szczęśliwej natury", która staje się rzecznikiem Boga, znajdujemy w wierszu początkowym z cyklu Już świt (,Już świt ... Purpury sq̨ na niebie...”) ${ }^{11}$, choć trzeba zaznaczyć, że w tej wyidealizowanej integracji bohatera z przyrodą pozostaje zgrzyt nie do końca przezwyciężony, ale osłabiony mocą wcześniejszych stwierdzeń, kreujących deklarowany niepodważalny lad oraz akceptujących ludzki los. Miciński uwydatnił tę niepodważalność wykrzyknikowymi apostrofami w końcowej strofie utworu:

Słońce! Ty jesteś ziemi królem -

Boże! Ty jesteś świata słońcem -

Duszo! Ty jesteś bóstwa gońcem -

Serce! Ty jedno - wiecznym bólem ${ }^{12}$.

Maria Podraza-Kwiatkowska pisząc o analizowanym tu wierszu, że jest zapisem seansu terapeutycznego, zauważa w jego puencie zgodę na los ofiary, akceptację cierpienia, która wynika „z religijnego uspokojenia i doznania piękna świata" i pokazuje alternatywę przyrody symbolizującej zagrożenie; w tym wypadku "natura nie przeraża, lecz zachwyca"13.

\footnotetext{
10 E. Kuźma, Oksymoron jako gest semantyczny w twórczości Tadeusza Micińskiego, [w:] Studia o Tadeuszu Micińskim, red. M. Podraza-Kwiatkowska, Kraków 1979, s. 195-226.

${ }^{11}$ W. Gutowski, op. cit., s. 58.

${ }^{12}$ T. Miciński, Wybór poezji, op. cit., s. 139.

13 M. Podraza-Kwiatkowska, Przedranna epifania Tadeusza Micińskiego (o wierszu «Już świt...»), [w:] Poezja Tadeusza Micińskiego, op. cit., s. 19-23.
} 


\section{Konsolacyjna moc przyrody i ofiara dla ojczyzny}

O ile „intymne pejzaże ocalenia” w wierszach Micińskiego z tomu $W$ mroku gwiazd występują nadzwyczaj rzadko i raczej jako nietrwałe enklawy, a ich „kosmiczna” odmiana wiąże się z doświadczeniem transgresji i wejścia na drogę prowadzącą ku Bogu ${ }^{14}$, o tyle wiersze Hymn i Widzenie Polski ukazują uładzoną wizję świata, w której jednostka dąży do innego wyższego celu - odbudowania ojczyzny.

Ogłoszony w czerwcowym numerze „Wsi Ilustrowanej” z roku 1914 (wraz z dwoma innymi tekstami: Wjaskini oraz Faun w lesie), Hymn jest wierszem przepełnionym patriotyzmem, utrzymanym w podniosłym tonie. Zwróćmy uwagę na czas publikacji: niecałe dwa miesiące przed początkiem zawieruchy wojennej. Miciński już wtedy snuje wizję odrodzenia Polski i określa jej przyszłe granice: „od Tatr aż po Balta Mare” - choć przecież przesłanki bezpośredniej ku temu nie było. Można powiedzieć, że jest to wizja prorocza, zapowiadająca wyzwoleńczy czyn poprzez kilkakrotne wezwania skierowane do rodaków:

Zbierajmy moc każdej duszy

w wieków ognisty lan -

kto jedną nikczemność skruszy

będzie Polakiem zwan!

(...) Idziemy na wielką górę

zbudować dla Orłów dom.

Na wielkiej górze Ornaku

zbierzem zaklęty huf -

w płomiennym serca krzaku,

w gontynie najświętszych słów...15.

Punktem wyjścia do kreowania pozytywnej wizji przyszłości Polski stają się tym razem, nie jak w innych późnych utworach Micińskiego „krzepiąca ducha” historia narodowa w powiązaniu z topiką biblijną i romantyczną (Elogium Ojczyzny, Wzniesienie krzyża, Katedra podziemna), nie bohaterowie literaccy i obrońcy ojczyzny, jak: Wallenrod

14 W. Gutowski, op. cit., s. 36.

15 T. Miciński, Hymn, „Wieś Ilustrowana” 1914, nr 6, s. 7-8. 
(Konrad), Czarniecki, Skarga i Batory, ale wiosenne rytmy natury, która objawia swój konsolacyjny potencjał:
Życie przeobrażone
w jeden cud...
Rzeki rwą rozelśnione, pokruszywszy lód.
Wiosenne ogrzane wody pełne kumkania żab - wyjdź do natury młodej, zakwita już brzoza i grab!
O jakież ciemne głębie, jak gdyby polski los - latają dzikie gołębie $\mathrm{w}$ dali gdzieś brzęki kos... ${ }^{16}$.

Apologia przyrody ma charakter totalny, synergiczna moc pierwiastków tellurycznych, faunicznych i florystycznych ewokuje obrazy odrodzenia narodowego i państwowego, podsuwa myśli o poświęceniu dla idei wolności, co zostanie uwyraźnione w dalszej części utworu. Obserwacje natury, ukazywanej tu w „rozsłonecznionej” wersji franciszkańskiego umiłowania świata, stają się impulsem do przemiany wewnętrznej podmiotu lirycznego wiersza. Sam poeta uwydatnia analogie między przyrodą a człowiekiem: „królestwo w sobie utwórzmy, / dziwne - jak Wiosny kwiat".

Ponadto, należy zauważyć, że te początkowe zwrotki zostały zapisane językiem cokolwiek uproszczonym. Środki stylistyczne są tu stosowane z umiarem, występuje brak sylabizmu i zmienny rytm mowy, jedynie podział stroficzny i rymy krzyżowe utrzymują porządek wypowiedzi. Podobną celową rezygnację $\mathrm{z}$ ornamentowości wiersza możemy dostrzec w Kasprowiczowskich tekstach zamieszczonych w Księdze ubogich. Miciński jest w tym wypadku również bardzo oszczędny w wykorzystywaniu swojej erudycji i odstępuje od efektownej metaforyki czy ulubionego chwytu oksymoronicznych przedstawien. Wszystkie te zabiegi mają zapewne służyć zwróceniu uwagi na sprawy najważniejsze. Kluczowym zagadnieniem w hymnie-ślubowaniu staje się zobowiązanie do

${ }^{16}$ Ibidem, s. 7. 
działania na rzecz narodu, które w tej formule zostaje dwukrotnie wpisane w ciąg wiersza (zwrotki czwarta i szósta brzmią prawie identycznie). Raz inwokacja zwrócona jest do „Promiennego ducha”, raz do ducha Bolesławów, jak w zakończeniu:

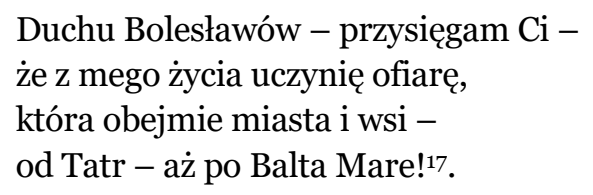

Interesującym kontekstem dla omówionego wyżej utworu jest Faun $w$ lesie, opublikowany wraz z Hymnem w tym samym numerze „Wsi Ilustrowanej"18. To tekst mówiący o niezwykłej i wiecznej sile przyrody, wśród której odpoczywa Faun. Znany jako staroitalskie bóstwo gór, lasów i łąk, tutaj symbolizuje naturę samą w sobie. Ascetycznie nagi fakir (mnich) tkwi w gęstwie tysiącletnich świerków i pośród stworzeń, do których ludzie nie przywiązują większej wagi. Poeta ukazuje nieprzewidywalność tego mikroświata chociażby $\mathrm{w}$ nagłym hiperbolicznym ruchu bzykającego owada, chcąc zapewne zwrócić uwagę na to, że może być on widziany analogicznie do świata istot rozumnych. Obydwa wiersze traktują o ewenementach natury poświadczających jej niezwykły ukryty potencjał, który może oddziaływać na pojedynczego człowieka i życie społeczeństw. A może ma również przełożenie na historiozofię ( $w$ wymiarze palingenetycznym). Cyklicznemu porządkowi przemian przyrody odpowiadałby wówczas cykliczny rytm procesów historycznych.

W Hymnie dochodzi do połączenia na zasadzie analogii mitu odrodzeńczego natury i mitu zmartwychwstałej ojczyzny - którą symbolizuje Duch Bolesławów. Warunkiem uskutecznienia i spełnienia tego drugiego staje się przemiana wewnętrzna „ja” mówiącego, zapowiadana $w$ przysiędze złożenia ofiary życia, która znajduje swój odpowiednik w wizjach działania wspólnoty narodowej. Mit wskrzeszenia jednostkowego, ledwie zarysowany, rozwija się w pochwalną pieśń symbolizującą poczucie jedności rodaków.

17 Ibidem, s. 8.

${ }^{18}$ T. Miciński, Faun w lesie, „Wieś Ilustrowana” 1914, nr 6, s. 8. 


\section{Widzenia Polski odrodzonej}

Nieco późniejszym, zupełnie dotąd nieznanym i nienotowanym przez badaczy wierszem Micińskiego jest Widzenie Polski, opublikowane najprawdopodobniej w 1915 roku $^{19}$ w kijowskim wydawnictwie finansowanym - i zapewne redagowanym - przez znaną wówczas autorkę powieści historycznych, Annę Grudzińską ${ }^{20}$. Także w tym utworze podobnie jak w Hymnie - początek wypełniają sceny pełnej życia przyrody, która, zgodnie z astronomicznym rytmem zmian pór roku, odradza się $\mathrm{w}$ wiosennym przebudzeniu:

Burza gdzieś idzie światami - tu zasię fioletowo-czarny
obłok nad ruinami zamku mroczy tam na górze.
Pod zamkiem kwitną srebrno różane sady w swoje krasie harnej²1.
Tucza jeszcze nie znikła, grom wciąż lśni w purpurze.
Wiosenna szmaragdowa ruń wśród chat rozrzuconych
po wzgórzach, z których spływa w królewskim majestacie
mrok - ciemny bór. Tęczuje rzeka pośród sadów ukwieconych²2.

${ }^{19}$ Książka, w której wydrukowano wiersz Micińskiego, jest opatrzona tytułem Jednodniówka oraz informacją o wydawcy: Skład Główny w Księgarni L. Idzikowskiego w Kijowie. Na stronie tytułowej brak daty. Natomiast na stronie 4, pod exlibrisem (emblematem) Drukarni Polskiej w Kijowie widnieje zapis: „Z pozwolenia wojennej cenzury 10 XII 1915.” Jest zatem bardzo prawdopodobne, że wydawnictwo ukazało się z końcem 1915 roku. Zawarte w nim teksty liryczne i prozatorskie zostały poprzedzone wprowadzeniem podpisanym kryptonimem A.G., które wyszło spod pióra Anny Grudzińskiej. Książka liczy 107 numerowanych stron, znaczną jej część (w wymiarze objętościowym) stanowią opowiadania Grudzińskiej, ponadto znalazło się tu klika wierszy Stanisława Karwickiego, utwory prozą Cecylii Niewiadomskiej i Ali Rosè-Drewnowskiej oraz poemat Micińskiego. Należy odnotować, że istnieje również inna - pierwsza - wersja opisanego tu wydawnictwa (z datą pozwolenia cenzury z sierpnia $1915 \mathrm{r}$.), w której występował ten sam wstęp oraz te same kolejne teksty do strony 39. Tom kończył wiersz Karwickiego Sfinks, który w drugim wydaniu został umieszczony w końcowej części książki, a jego miejsce zajął inny pt. Skowronek. W pierwszej wersji Jednodniówki nie znalazł się zatem poemat Micińskiego. Była natomiast informacja, że książka ukazuje się nakładem Anny Grudzińskiej z miejscowości Derewicze w guberni wołyńskiej.

${ }^{20}$ Anna Grudzińska była autorką wielu powieści historycznych odnoszących się do dziejów Polski, przeznaczonych głównie dla młodzieży. Do najbardziej poczytnych należały m.in. Mnich. Powieść historyczna z XI w., z czasów Rychezy i Odnowiciela (1909), Nad Dniestrem. Powieść z czasów Zygmunta Wazy (1912), W stepie. Powieść historyczna dla młodzieży (1913), zob. G. Skotnicka, Dzieje piórem malowane. O powieściach historycznych dla dzieci i młodzieży z okresu Młodej Polski i dwudziestolecia międzywojennego, Gdańsk 1987, s. 56-57, 59, 327-328, passim. W latach Wielkiej Wojny pisarka prowadziła polską akcję oświatową na Wołyniu.

${ }^{21}$ Harny, czyli „łączący w sobie żywość, piękność, odwagę”. Zob. J. Karłowicz, Stownik gwar polskich, t. 2, Kraków 1901, s. 170. Tu też w znaczeniu dzikości przyrody, jej siły. ${ }^{22}$ T. Miciński, Widzenie Polski, [w:] Jednodniówka, Kijów 1915, s. 83. 
Jednak - w odróżnieniu od poprzednio analizowanego utworu daje się tutaj zauważyć miast idyllicznej i jednolitej stylistycznie wizji uładzonej natury antynomiczność obrazowania. Ścierają się ze sobą światło i mrok, mimo to dominuje jakaś magiczna aura olśnienia. Ze zmieszania żywiołów rodzi się napięcie, które zapowiada nadejście metamorfozy świata. Rzeczywistość przedstawiana jest dwojako. Miciński operuje zmienną perspektywą: obok szczegółów życia w konkretnym miejscu, u podnóża pozostałości po starym zamku, ukazuje to, co się dzieje w wymiarze globalnym, sygnalizuje w sposób metaforyczny zmiany dokonujące się ponad małym wycinkiem rzeczywistości w ujęciu makroperspektywy.

W udramatyzowanej strukturze poematu odsłania się przed nami kolejna jego scena, będąca zawiązaniem akcji: wychodzi książę, który „zapragnął ujrzeć tajń ziemną”. Dostrzegłszy porzucony pług, zaprzągł konie i rozpoczął orkę. Praca na roli otwiera przed nim skarby natury. Utrudzony, posila się pszczelim miodem i wodą ze źródła. Wzbierają w nim nadludzkie siły. Podczas pracy, w której towarzyszy mu rój pszczół, doznaje epifanii Boga:

Tak idzie niezmęczony, choć pali żar połednia.

Rój, lecąc wciąż nad nim gra y koronuje.

Bruzdy olbrzymie rzuca, jakby okrętem steruje.

Natenczas poznał jednak, że ktoś tu niewidzialny

rzuca pszeniczne dżdże! Więc w kruży skalnej

zamiast jeść miód, w modlitwę szedł - gdzie Jednia

Natury, człowieka y Twórczego Bóstwa ${ }^{23}$.

Gdy zmęczony bohater zasypia, w śnie zjawiają mu się dziwożony24, z których jedna zasiewa ziarno, ale znika w kmiecej stodole. Po ocknięciu się, książę wspomina o zmarłej ukochanej i uświadamia sobie, że jest samotny, że nie ma z kim założyć rodziny. Jednak kontynuuje orkę. Nagle,

23 Ibidem, s. 84.

${ }^{24}$ Złośliwe postacie znane z polskich podań i legend ludowych, inaczej dziwobaby, demoniczne istoty żeńskie, zamieszkujące pod ziemią, w osypiskach skalnych, pieczarach i jeziorach, zob. B. Podgórska, A. Podgórski, Wielka księga demonów polskich. Leksykon i antologia demonologï ludowej, Katowice 2005, s. 183. Zwane niekiedy „straszydłami Tatr”, z racji występowania w baśniach z Podhala (oraz Małopolski), opisywane przez Kazimierza PrzerwęTetmajera w Bajecznym świecie Tatr. Zob. B. Walęciuk-Dejneka, Ludowy obraz kobiety pespektywa inności, Siedlce 2014, s. 225-253 (rozdz. III: Niewierność prześladowana dziwożony). 
już przy jej końcu, lemiesz wydaje dźwięczący ton i wtedy książę odnajduje zakrwawiony miecz wbity w skałę. Doznaje kolejnego olśnienia:

(...) domyślił się, że to kurhan dawny i że z jego trzew

Bije wciąż Tajemnica!

Tak więc, to los nasz - wyorywać miecze

tam gdzie by się chciało wejść do jasnej Chaty!

To los nasz - przed którym żaden Polak nie uciecze -

zaorać ziem - i nim plon wejdzie iść żołnierzem w światy!...25

Mit agrarny, odwołujący się do unii człowieka z naturą w zakresie współdziałania, został tu uzupełniony odrodzeńczym mitem historii narodowej, „odkopanej” w dawnym miejscu pochówku. Symbolizuje ten mit ostatni miecz przodków - miecz legenda, który staje się wezwaniem do działania. Jedność z ziemią to z jednej strony jej uprawa, ale z drugiej, zgodnie z wierzeniami Słowian - także wierność przodkom, pamięć o ich grobach. Wreszcie książę uświadamia sobie, że jego obowiązkiem jest bycie wojownikiem, czyli walka. Także to, że sen o dziwożonie był tylko demonicznym zwidem, sielankowym marzeniem o uporządkowaniu własnego życia. Teraz krytykuje postawę człowieka dbającego jedynie o sprawy prywatne, przeciwstawia im kwestie wyższe, narodowe.

Jego metamorfoza - czyli samoprzezwyciężenie - to powtórzenie schematu pozytywnej reintegracji jednostki, który występował w wielu wcześniejszych utworach autora Xiedza Fausta. Już kilkadziesiąt lat temu Wojciech Gutowski opisywał ów ruch wewnętrzny w procesie rozwoju bohatera, odbywający się w układzie wertykalnym góra - dół, który zazwyczaj wymagał zstąpienia do piekieł, ciemności lub podziemia, by móc później wybić się ponad sfery upadku²6. W Widzeniu Polski ten proces reintegracyjny został przedstawiony następująco:

Żegnajcie mi bracia - wy rycerscy kmiecie! dotąd jest Polak smętnym jeno apostołem, co wzywa na szczyt gór - a tęskni za Siołem,

\footnotetext{
25 T. Miciński, Widzenie Polski, op. cit., s. 85.

${ }^{26}$ Mam tu na uwadze pracę z 1980 r. W poszukiwaniu życia nowego, przedrukowaną później w innej książce, opus magnum badacza, Zob. W. Gutowski, Wprowadzenie do Xięgi Tajemnej. Studia o twórczości Tadeusza Micińskiego, Bydgoszcz 2002, s. 63-64. W dalszym ciągu rozważań autor w odniesieniu do dramatu Veni Creator opisuje schemat odrodzenia jako „wejście w głębie i powrót-wzlot” (ibidem, s. 68).
} 
gdzie będzie mógł z Anioły zasiąść i przy swej kobiecie.

Żegnajcie kmiecie! Niech wam błogosławy

śle Słońce życiodajne y ziemia mogilna!

Schodzę w podziemia, aby z mrocznej nawy

trumna Zmartwychwstań wyszła - a w niej Dusza Silna!...27

Kluczowym w tym fragmencie jest słowo „Zmartwychwstanie”, wyróżnione poprzez zapis dużą literą. To oczywiste nawiązanie do symboliki odrodzenia, według Gutowskiego, wykorzystywanej w poezji autora Kniazia Patiomkina jako podstawowy wariant reintegracji ${ }^{28}$. Tyle że tym razem nie ma mowy o niszczącej sile natury, jest ona raczej impulsem do poczucia jedni świata. Natura i jej zew, który u księcia wyzwala atawistyczny odruch chwycenia za pług, prowadzą do przemiany wewnętrznej, do czynu egzystencjalnego. Mit odrodzenia funkcjonuje w stanie uruchomienia pierwotnych instynktów i autorefleksji bohatera. Projektowanie „Duszy Silnej” przypomina nietzscheańską transgresję, odbywającą się na zasadzie emanowania woli mocy prowadzącej do nadczłowieka. Zresztą, Nietzsche widział także sens w jedności z naturą, w wykorzystywaniu jej sił dla własnego wzmocnienia ${ }^{29}$. W jego mniemaniu, powrót do pierwotności to sięganie do sił głębinowych w człowieku, czyli naturalnych.

Przyjrzyjmy się dalszym fragmentom poematu. Zmienia się sceneria. Książę spotyka się z pustelnikiem Adamem, który prowadzi go przez wielkie wody. Są to wody życia, przelewające się przez obszar ziem polskich, także przez mogilne miejsca. Homeryckie porównanie przywołuje na myśl obraz biblijnego potopu. Pustelnik, występujący tutaj w roli Nauczyciela i Mistrza, rysuje przed swoim uczniem obraz uzdrowienia wszystkiego, co zostanie obmyte przez wodę:

Żyć będzie wszystko, dokąd sięgnie potok - i uzdrowione

będzie wszystko! Zaś dusze będą jako ryby,

pływające w tem morzu szczęścia...

${ }_{27}^{7}$ T. Miciński, Widzenie Polski, op. cit., s. 86.

${ }^{28}$ W. Gutowski, Wprowadzenie do Xięgi Tajemnej, op. cit., s. 64.

29 Zob. m.in. opinię o postępie w: F. Nietzsche, Zmierzch bożyszcz, czyli jak filozofuje się młotem, wstęp i tłum. G. Sowiński, Kraków 2013, s. 32: „Postęp w moim rozumieniu. Również ja mówię o «powrocie do natury», choć właściwie nie jest to ruch wstecz, lecz w górę - ku wyżynnej, wolnej, nawet straszliwej naturze i naturalności, takiej, która igra, której wolno igrać wielkimi zadaniami...”. 
Ta wizja idylliczna, ukazująca przestrzeń nietypową w poezjach Micińskiego ze względu na swoje optymistyczne nacechowanie, uzupełniona została kolejną, która przedstawia konkretny geograficzny obraz przyszłej ojczyzny:
(...) Ta jest ziemi tej granica:
od morza aż do rzeki Łaby, gdzie dawne sadyby
Xiążęciów ślązkich - i tam gdzie Rodzica
rzek naszych Wisła i tam aż po Dniestry -
gdzie Polska żywa, lub gdzie mogił zaświadczą rejestry!3o

Należy dodać, że we wcześniejszych wersach poematu zaznaczone zostały oprócz tych tutaj zakreślonych granic zachodnich i wschodnich kraju, także północna - to Morze Bursztynowe (Bałtyckie) i południowa: Tatry.

Ryt odrodzenia ukazany został w utworze poprzez odniesienia do dzikiej i pięknej przyrody, sięganie do mitu agrarnego, a także do biblijnego motywu ożywienia za pomocą wody życia (jak w Apokalipsie św. Jana) lub oczyszczającego obmycia wodą, co można by potraktować jako nawiązanie do Psalmu 50. Starego Testamentu (chociaż trzeba pamiętać, że wody życia, o których mówi pustelnik, będą obmywały całą polską ziemię - a nie pojedynczego człowieka). Nie zapominajmy, że w mitach, baśniach i podaniach polskich również wielokrotnie występuje motyw magicznej wody życia ${ }^{31}$, która uzdrawia, ożywia i daje nieśmiertelność. A Miciński był znawcą kultury ludowej i często się do niej odwoływał, zatem możliwa jest i taka proweniencja motywu akwatycznego.

Wiersz na tle publicystycznej poezji Micińskiego czasu wojny32 zadziwia swoją odmiennością. Wynika to z przyjętej formuły wypowiedzi: rodzaju przypowieści, w której najważniejsze są treści alegorycznosymboliczne, jak również dydaktyczne. Akcenty religijne są istotne, ale nie ma tu jednoznacznego odwołania do mitu odrodzenia religijnego,

\footnotetext{
${ }^{30}$ T. Miciński, Widzenie Polski, op. cit., s. 86-87.

${ }^{31}$ Por. np. J. Krzyżanowski, Paralele. Studia porównawcze z pogranicza literatury i folkloru, Warszawa 1961, s. 318-319; także: J. Maślanka, Literatura a dzieje bajeczne, Warszawa 1984, s. 262.

${ }^{22} \mathrm{O}$ związkach wojennej liryki Micińskiego z publicystyką pisał Jarosław Ławski, wskazując jej agitacyjność i felietonowość. Zob. J. Ławski, «Pszenica i kąkol». Wyobraźnia poetycka Tadeusza Micińskiego w latach „Wielkiej Wojny”, [w:] Poezja Tadeusza Micińskiego. Interpretacje, op. cit., s. 442, 462.
} 
występującego $\mathrm{w}$ koherencji $\mathrm{z}$ rytem wskrzeszenia narodu, jak we Wzniesieniu krzyża33 - wierszu powstałym w tym samym czasie.

$$
* * *
$$

W obydwu analizowanych wyżej późnych utworach poetyckich Tadeusza Micińskiego występuje mit odrodzeńczy w kilku wariantach: przyrodniczym, osobowym i narodowym (państwowym). $\mathrm{Z}$ innych wcześniejszych tekstów pisarza znamy głównie te dwa ostatnie. Specyficzność wizji, jakie odnajdujemy we wspomnianych wierszach, pozwala na ich wyróżnienie jako przejawu innowacji warsztatu artystycznego. Po pierwsze, wynika to z zarzucenia języka publicystyki i erudycji historyczno-kulturowej. Nie ma bezpośrednich obrazów Wojny, Wygnania, Cierpienia, Inferna i Konrada. To jasne obrazy (nie ciemne), przypominające franciszkańskie umiłowanie przyrody, poczucie wolności i otwarcie na sprawy innych ${ }^{34}$. Po drugie, skupienie uwagi na kwestii odzyskania niepodległości kraju stało się możliwe dzięki użyciu oszczędnej mowy symbolicznej oraz ukazywaniu jedności człowieka z przyrodą - jego harmonijnej z nią koegzystencji. Nie jest już ona siedliskiem zła, a jej dzikość to raczej źródło energii, także wskazanie na ludzką pierwotną siłę, nieskażoną kulturą. Jednakże zachwyty czy olśnienia widokiem odradzającej się wiosennej przyrody, zarówno w Hymnie, jak i w Widzeniu Polski, są tylko punktem odniesienia i impulsem do duchowego postępu. Człowieczeństwo szuka wartości wyższych: wspólnych, czyli społecznych - tu zarazem narodowych. W wizjach poety jawi się Polska wskrzeszona w konkretnych kształtach geograficznych, zbudowana na wyrzeczeniu się szczęścia prywatnego. W sytuacji wojny, będącej szansą na wyzwolenie z okowów niewoli, każdy staje się żołnierzem. Takie jest przesłanie obydwu wierszy35.

33 T. Miciński, Wzniesienie krzyża, „Echo Polskie” 1915, nr 1, s. 6.

34 Tak charakteryzowała Irena Maciejewska przyświecające młodopolskim pisarzom idee franciszkanizmu, które wcześniej opisał Edward Porębowicz, zob. I. Maciejewska, Franciszkanizm $w$ poezji Młodej Polski, [w:] Problematyka religijna $w$ literaturze pozytywizmu i Młodej Polski. Świadectwa poszukiwań, red. S. Fita, Lublin 1993, s. 313-315. 35 Widzenie Polski, traktowane tutaj jako osobny wiersz, według informacji zamieszczonej w przypisie pod jego tekstem, było „fragmentem z dużego Eposu, pisanego stylem staropolskim o wojnie obecnej”. Należy przyjąć, że jest to ogniwo poematu Wyprawa do Wojsk Zaśnionych $w$ Tatrach, o którym mowa w uwadze do publikacji innego utworu z czasów Wielkiej Wojny, występuje w nim również postać Księcia - kmiecia. Zob. T. Miciński, Elogium Oyczyzny, [w:] Na wpisy szkolne. Jednodniówka Tow. Dziennikarzy i Literatów Polskich, Warszawa 1915, s. 22. 


\section{Literatura / References}

Gutowski W., Wprowadzenie do Xięgi Tajemnej. Studia o twórczości Tadeusza Micińskiego, Bydgoszcz 2002.

Gutowski W., Wstęp, [w:] Tadeusz Miciński, Wybór poezji, wstęp i oprac. W. Gutowski, Kraków 1999, s. 5-68.

Karłowicz J., Stownik gwar polskich, t. 2, Kraków 1901.

Krzyżanowski J., Paralele. Studia porównawcze z pogranicza literatury i folkloru, Warszawa 1961.

Kuźma E., Oksymoron jako gest semantyczny $w$ twórczości Tadeusza Micińskiego, [w:] Studia o Tadeuszu Micińskim, red. Maria PodrazaKwiatkowska, Kraków 1979, s. 195-226.

Ławski J., Kosmografia wolności. „Nowe” pisma Tadeusza Micińskiego z lat 1914-1917, „Wiek XX. Rocznik Towarzystwa Literackiego im. Adama Mickiewicza" 2018, R. 11, s. 157-170.

Ławski J., «Pszenica i kakol». Wyobraźnia poetycka Tadeusza Micińskiego $w$ latach „Wielkiej Wojny”, [w:] Poezja Tadeusza Micińskiego. Interpretacje, red. A. Czabanowska-Wróbel, P. Próchniak, M. Stala, Kraków 2004, s.431-493.

Maciejewska I., Franciszkanizm w poezji Młodej Polski, [w:] Problematyka religijna $w$ literaturze pozytywizmu $i$ Młodej Polski. Świadectwa poszukiwań, red. S. Fita, Lublin 1993, s. 309-327.

Maślanka J., Literatura a dzieje bajeczne, Warszawa 1984.

Miciński T., Elogium Oyczyzny, [w:] Na wpisy szkolne. Jednodniówka Tow. Dziennikarzy i Literatów Polskich, Warszawa 1915, s. 22-23.

Miciński T., Faun w lesie, „Wieś Ilustrowana” 1914, nr 6.

Miciński T., Hymn, „Wieś Ilustrowana” 1914, nr 6.

Miciński T., Poematy proza, oprac. W. Gutowski, Kraków - Wrocław 1985.

Miciński T., Poezje, oprac. J. Prokop, Kraków - Wrocław 1980, wyd. 2. 1984.

Miciński T., Widzenie Polski, [w:] Jednodniówka, Kijów 1915, s. 83-87.

Miciński T., Wybór poezji, wstęp i oprac. W. Gutowski, Kraków 1999.

Miciński T., Wzniesienie krzyża, „Echo Polskie” 1915, nr 1.

Nietzsche F., Zmierzch bożyszcz, czyli jak filozofuje się młotem, wstęp i tłum. G. Sowiński, Kraków 2013.

Podgórska B., Podgórski A., Wielka księga demonów polskich. Leksykon $i$ antologia demonologii ludowej, Katowice 2005.

Podraza-Kwiatkowska M., Przedranna epifania Tadeusza Micińskiego (o wierszu «Już świt...»), [w:] Poezja Tadeusza Micińskiego. Interpretacje, red. A. Czabanowska-Wróbel, P. Próchniak, M. Stala, Kraków 2004, s. 7-24.

Próchniak P., Postscriptum: notatki o czytaniu Micińskiego, [w:] Poezja Tadeusza Micińskiego. Interpretacje, red. A. Czabanowska-Wróbel, P. Próchniak, M. Stala, Kraków 2004, s. 495-506. 
Skotnicka G., Dzieje piórem malowane. O powieściach historycznych dla dzieci $i$ młodzieży $z$ okresu Młodej Polski $i$ dwudziestolecia międzywojennego, Gdańsk 1987.

Sobieraj S., Publicystyka Tadeusza Micińskiego $w$ dobie Wielkiej Wojny, [w:] Czytać Tadeusza Micińskiego. Studia, red. A. Czyż, M. Pliszka, S. Sobieraj, Siedlce 2016, s. 163-185.

Walęciuk-Dejneka B., Ludowy obraz kobiety - pespektywa inności, Siedlce 2014.

Wasilewski Z., Miciński i jego los, „Gazeta Warszawska” 1925, nr 75.

Witkiewicz St. I., 622 upadki Bunga, czyli Demoniczna kobieta, wstęp i oprac. A. Micińska, Warszawa 1972.

Wydrycka A., Tadeusz Miciński i Pierwszy Zjazd Wojskowych Polskich $w$ Piotrogrodzie $w 1917$ roku. Zapomniane artykuly i poematy, [w:] Proza Tadeusza Micinskiego. Studia, red. M. Bajko, W. Gutowski, J. Ławski, Białystok 2017, s. 163-206.

Wydrycka A., Zapomniane teksty Micińskiego, „Ruch Literacki” 1989, z. 4-5, s. 381-394. 